\title{
ПСИХОЛОГІЧНІ АСПЕКТИ АВТОРСЬКОЇ СТРАТЕГІЇ ПЕРЕКЛАДУ
}

\section{Івашкевич Ернест Едуардович}

Пошукувач кафедри вікової та педагогічної психології Рівненського державного гуманітарного університету, м. Рівне (Украӥна)

\begin{abstract}
Анотація. В статті розглянуто психологічні аспекти перекладацької діяльності. Зазначено, щуо перекладач здійснює мовленнєве посередництво, за умов якого мовою перекладу створюється певний текст, комунікативно рівноцінний оригіналу, при чому його комунікативна рівночінність виявлясться в ї̈ ототожненні перекладачем з оригіналом в функціональному, змістовому і структурному планах. Автором описано перекладацькі стратегї, які мають місце стосовно перекладу художньої літератури, а саме: включення в текст додаткових елементів (авторські вкраплення у перекладі); опущення елементів, надлишкових з точки зору іншомовного читача; перетворення смислової структури слів $і$ виразів; компромісні перекладацькі рішення; використання адекватних замін (інтерпретація, антонімічний переклад, компенсація $i$ т.д.); знаходження функиіонального аналога; суто авторський переклад.

Охарактеризовано особливості суто авторської стратегї перекладу спрямованої на відображення експліцитних та імпліцуитних значень периотвору з метою збереження щзонайбільшої свободи інтерпретації. Окреслено випадки непрямого перекладу тексту із привнесенням авторського смислу, запропоновано їхні тлумачення. Сформульовано додаткову стратегію у перекладі художніх творів, яку визначено як стратегію ампліфікації, обгрунтовано зміст иiєё cmpameziï.
\end{abstract}

Ключові слова: перекладацька діяльність, мовні фактори, екстралінгвістичні фактори, перекладаџькі стратегії, суто авторська стратегія перекладу, стратегія ампліфікаџії.

\section{Постановка проблеми та іï актуаль-}

ність. Визначення психологічних аспектів перекладацької діяльності завжди було й досі залишається актуальною проблемою сучасності. Адже перекладач здійснює мовленнєве посередництво, за умов якого мовою перекла- ду створюється певний текст, комунікативно рівноцінний оригіналу, при чому його комунікативна рівноцінність виявляється в ії ототожненні перекладачем з оригіналом в функціональному, змістовому і структурному планах.

Аналіз останніх досліджень і публіка- 
цій. Вчені Дж. К. Кетфорд [3], Л. В. Коломієць [4], В. Н. Комісаров [5], Ю. М. КриловаГрек [7] та ін. зазначають, що перекладач як учасник складного процесу спілкування одночасно виконує декілька комунікативних функцій. По-перше, він передає текст оригіналу, тобто бере участь в звичайному акті спілкування. По-друге, перекладач $є$ творцем тексту мовою перекладу, тобто $є$ співавтором новоствореного тексту. По-третє, перекладач створює не просто текст мовою перекладу, а такий текст, який у функціональному, змістовому i структурному планах постає в якості повноправної заміни оригінала. А це означає, що перекладач порівнює мовленнєві еквіваленти одиниць мови, вишукує найбільшою мірою еквівалентні одиниці в мові перекладу, будує 3 них дискурсивні мовленнєві утворення, порівнює їх з оригінальними, обирає остаточний варіант перекладу тощо. Тим самим перекладач стверджує комунікативну рівність двох відрізків тексту, написаних різними мовами. Отже, процес перекладу і його результат цілковито залежать від комунікативних можливостей перекладача, його знань і вмінь, тобто, перекладацької компетентності.

I якщо проблема перекладацької компетентності досить глибоко розкрита в психологічних дослідженнях (Т. О. Долга [1], О. С. Кочубей [6], Н. О. Михальчук [8] та ін.), то своєрідна «психологізованість» окремих стратегій перекладу й досі залишається поза увагою дослідників. Тому завданнями нашої статті є:

1. Окреслити задачі перекладацької діяльності.

2. Описати перекладацькі стратегії, які мають місце стосовно перекладу художньої літератури.

3. Охарактеризувати особливості суто авторської стратегії перекладу, спрямованої на досягнення досить важливої мети професійної діяльності перекладача, а саме відображення експліцитних та імпліцитних значень першотвору з метою збереження щонайбільшої свободи інтерпретації, навести приклади перекладу О. Логвиненком твору Дж. Д. Селінджера із використанням стратегії «суто авторський переклад».

\section{4. Окреслити випадки непрямого перек-} ладу тексту із привнесенням авторського смислу, запропонувати їхні тлумачення.

5. Сформулювати додаткову стратегію у перекладі художніх творів, яку визначено як стратегію ампліфікації, обгрунтувати зміст цієї стратегії.

\section{Виклад основного матеріалу і резуль-} татів дослідження. В перекладацькій діяльності, зазначає I. О. Зимня [2, с. 19-23], в якості квазі-ідентичних форм одного і того ж самого повідомлення постають тексти, створені на основі різних мовних систем та одиниць, які не співпадають ні за формою, ні за змістом. Ось чому розбіжності між перекладеними текстами зумовлюються вже не стільки індивідуальними відмінностями комунікантів, скільки 
відмінностями між мовами. Зазвичай, індивідуальні відмінності також існують, але вони відходять на другий план. Ось чому сама можливість і закономірності виконання перекладу визначаються, в першу чергу, здатністю різних текстів поставати в якості комунікативно рівноцінних в процесі здійснення фахівцем перекладацької діяльності.

Найважливішою задачею перекладацької діяльності є виявлення мовних і екстралінгвістичних факторів, які уможливлюють ототожнення змісту повідомлення, що передається, різними мовами. Спільність змісту (змістова наближеність) текстів оригіналу i перекладених текстів називається еквівалентністю перекладу (оригінала). Вивчення реальних відносин між змістом оригіналу і перекладом дозволяє встановити межі цієї спільності, тобто максимально можливу змістову близькість текстів, написаних різними мовами, а також визначити їхню мінімальну ступінь близькості до оригіналу, за умов якої даний текст може бути цілком визнаний еквівалентним перекладом [3, с. 97].

Цілком або частково еквівалентні одиниці та потенційно рівноцінні текстові фрейми об'єктивно існують у перекладацькій діяльності, проте їх правильна оцінка, відбір і використання залежать від знань, умінь, творчих здібностей та перекладацької компетентності фахівця, від його умінь враховувати і порівнювати всю сукупність мовних, мовленнєвих та екстралінгвістичних факторів. В процесі здій- снення перекладацької діяльності спеціаліст вирішує складну задачу знаходження й адекватного використання необхідних елементів системи еквівалентних одиниць, на основі якої створюються комунікативно рівноцінні висловлювання у двох мовах. Об'єктивносуб'єктивний характер притаманний всій діяльності перекладача, і його дії ніколи не зводяться до суто механічної підстановки одиниць перекладу замість одиниць оригіналу. В науковій царині існує думка про те, що «переклад починається там, де закінчується словник» [11, с. 93]; вона досить помилково припускає, що за умов наявності словникової відповідності задачею перекладача є лише механічне перенесення такої відповідності в текст перекладу. 3 урахуванням цього підходу перекладацька творчість зводиться лише до прийняття нетривіальних унікальних рішень, необхідних в таких досить унікальних випадках, як переклад образів, каламбурів, жаргонізмів і т.д. Таким чином, теоретичні і практичні проблеми перекладу пов'язані не 3 периферійними явищами, а з використанням всіх ресурсів мови для досягнення перекладачем задач кроскультурної комунікації, вважає Н. О. Михальчук $[8$, с. 51$]$.

Стосовно перекладу художньої літератури, ми виокремлюємо наступні перекладацькі cmpameziï:

- включення в текст додаткових елементів (авторські вкраплення у перекладі);

- опущення елементів, надлишкових 3 
точки зору іншомовного читача;

- перетворення смислової структури слів і виразів;

- компромісні перекладацькі рішення;

- використання адекватних замін (інтерпретація, антонімічний переклад, компенсація і т.д.);

- знаходження функціонального аналога;

- суто авторський переклад.

Ми вважаємо, що суто авторська стратегія перекладу спрямована на досягнення досить важливої мети професійної діяльності перекладача, а саме відображення експліцитних та імпліцитних значень першотвору з метою збереження щонайбільшої свободи інтерпретації. Наведемо приклади перекладу О. Логвиненком твору Дж. Д. Селінджера із використанням стратегії «суто авторський переклад», які, на наш погляд, найбільшою мірою психологізують перекладений еквівалент твору.

Наприклад, «lousy childhood» [10, с. 1] перекладається О. Логвиненком як «безголове дитинство» $[9$, с. 1]. Тоді як в словниках слово «lousy» перекладається як «нікчемний», «відстій», «гальмо», «безглуздий», «мерзенний» (розм. лексика). Як жаргон «lousy» перекладається «чмошний», «відстійний». Загальноприйнятими є такі значення цього слова: «вшивий», «низький», «паршивий», «гидотний», «дряний», «брудний», «непорядний», «мізерний» тощо.
Лайливим $\epsilon$ переклад даного слова «херовий», а вульгаризмом вважається «огидний» [12]. Тому переклад даного словосполучення О.Логвиненком будемо вважати непрямим перекладом із привнесенням авторського смислу, адже прямим перекладом цього словосполучення мало б бути «нікчемне дитинство» чи «паршиве, «гидотне, «дряне дитинство» тощо.

Слово «lousy» вживається також і в інших словосполученнях, які мають різні значення при перекладі на українську мову. Наприклад:

- «...that the only reason he was lousy at writing compositions» $[10$, c. 12] - «...нібито в нього так паскудно виходять твори» [9, с. 17].

- «She had a lousy childhood» [10, c. 14] «Дитинство в неї було паршиве» [9, с. 20].

- «...a lousy movie» $[10$, c. 15-16] - «... зачуханий фільм» [9, с. 22].

- «It took me about an hour, because I had to use Stradlater's lousy typewriter, and it kept jamming on me» [10, с. 17] - «Просидів я добру годину - друкувати довелося на Стредлейтеровій машинці, а вона, клята, всю дорогу заїдала» [9, с. 24].

- «Get your lousy knees off my chest» [10, c. 19] - «Забери з грудей свої ідіотські коліна!» $[9$, с. 26].

- «Stradlater said you had a lousy personality» [10, с. 21] - «Стредлейтер сказав, ніби ти - паскудний хлопець» [9, с. 29].

- «I can even read one of those lousy 
stories on a train at night, usually» [10, c. 23] «Вночі в поїзді, кажу ж, я звичай по можу читати навіть таку муру» [9, с. 32].

- «I'm not kidding, the hotel was lousy with perverts» [10, с. 27] - «Той готель був просто напханий психами, серйозно кажу» [9, с. 37].

- «...but they gave me a lousy table anyway» $[10$, с. 30$]$ - «...але стіл мені дали однаково занюханий» $[9$, с. 41].

Вираз «but I don't feel like going into $i t\rangle[10$, c. 1] також перекладається із використанням суто авторського перекладу, а саме «я не маю охоти закопуватись у той мотлох» $[9$, с. 1]. Таким же чином перекладається «my parents would have about two hemorrhages apiece» $[10$, с. 1] - «і батька, й матір моїх по двічі вхопив би грець кожного» $[9$, с. 1]. Хоча сам по собі вираз «to have about two hemorrhages apiece» перекладається як «ось тобі на», «оце так!», «ну треба же!»

«Old Selma Thurmer» [10, с. 1] перекладається як «Сельма Тернер, каналія» [9, с. 2], тоді як слово «old» перед ім'ям має значення «старий друже» [12]. Інші приклади такого типу:

- «Old Marsalla» [10, с. 7] - «Оце-то Марсалла!» $[9$, с. 10].

- «Old Ossenburger Memorial Wing» [10, c. 8] - «імені отого самого Оссенбергера» [9, c. 10].

- «after I left old Spencer» [10, c. 8] «коли після квартири старого Спенсера» [9, с. $11]$.
- «old Thomas Hardy» [10, c. 8] «каналії Томасові Гарді» [9, с. 11].

- «old Ackley» [10, с. 8] - «каналія Еклі» $[9$, с. 11$]$.

- «and watched old Ackley making himself at home» [10, с. 9] - «що почував себе тут, каналія, як удома» [9, с. 13].

- «Old Stradlater» [10, с. 13] - «Каналія Стредлейтер» $[9$, с. 18].

- «Old Stradlater laughed» [10, c. 13] «Каналія Стредлейтер - у сміх» [9, с. 18].

- «and getting old Stradlater» [10, c. 13] «й зробити каналії Стредлейтерові» [9, с. 18].

- «Old Stradlater» [10, с. 14] - «Каналія Стредлейтер» [9, с. 19].

- «...old Jane» [10, с. 14] - «...каналію Джейн» $[9$, с. 20].

- «...old Thurmer» $[10$, c. 15] - «... каналія Термер» $[9$, с. 22].

- «You could also hear old Ackley snoring» $[10$, c. 17] - «Та ще було чути, як хропе каналія Еклі» [9, с. 24].

- «old Stradlater was standing practically right on top of me» [10, с. 19] - «а каналія Стредлейтер стояв наді мною» [9, с. 27].

- «Old Ackley put his hand up» [10, c. 20] - «Еклі, каналія, затулився долонею» [9, с. 28].

- «But old Stradlater» [10, c. 21] - «Але каналія Стредлейтер» [9, с. 30].

- «... and see what old Mal Brossard was doing» $[10$, c. 22] - «...і поглянути, як там поживає каналія Мел Броссард» [9, с. 31].

- «I figured my parents probably wouldn't 
get old Thurmer's letter saying I'd been given the ax till maybe Tuesday or Wednesday» [10, c. 22] - «Листа від каналії Термера про те, що мене вигнали зі школи, мої старі одержать, певно, десь у вівторок чи в середу» [9, с. 31].

- «The thing is, though, I liked old Morrow's mother» [10, с. 24] - «Але мати каналії Морроу мені сподобалася» [9, с. 33].

- «Well, a bunch of us wanted old Ernie to be president of the class» [10, c. 24] - «Багато хлопців хотіли вибрати каналію Ерні старостою класу» [9, с. 34].

- «...of giving old Jane a buzz» [10, c. 27] - «... як би його зателефонувати каналії Джейн» [9, c. 38].

- «When old Donat» [10, c. 29] - «Приміром, коли каналія Донат» [9, с. 40].

- «...only old Phoebe spells it «Hazle» [10, c. 29]

- «Тільки Фібі, каналія, пише «Гейлз» [9, с. 41].

- «Old Phoebe» [10, c. 29] - «Оце-то Фібі, каналія!» [9, с. 41].

Слово «Воу...» («Boy, I rang that doorbell fast when I got to old Spencer's house» [10, c. 2]) на початку речення у побутовому стилі перекладається як «Слухайте...» («Слухайте, коли я нарешті добіг до дверей старого Спенсера, то натис на дзвінок мов скажений») [9, с. 3]. Наведемо інші приклади:

- «Boy, his bed was like a rock» [10, c. 3] «Слухайте, в нього не ліжко, а справжній камінь!» [9, с. 5]

- «Boy, I couldn't've sat there» [10, c. 7] -
«Слухайте, я не просидів би там» [9, с. 9] У даному прикладі розмовне «слухайте» зумовлено ще й графоном «couldn't've».

- «Boy, did he look worried» [10, c. 19] «Слухайте, а він таки не на жарт злякався!» [9, c. 27]

- «Boy, did that annoy me» [10, c. 20] «Слухайте, це вже мені набридло!» [9, с. 29]

- «He was the perfect host, boy» [10, c. 21] - «До чого ж гостинний господар, слухайте!» $[9$, c. 30]

- «Boy, was she lousy with rocks» [10, c. $24]$ - «Слухайте, та в- неї ж усі пальці в камінцях!» [9, с. 33]

- «Boy, he's really shy» [10, c. 25] «Слухайте, він справді дуже сором'язливий» $[9$, с. 34$]$.

Суто авторським є переклад речень 3 іменником «guy»: «...with a guy like Ackley» [10, с. 9] - «3 таким фруктом, як Еклі» [9, с. 13]. В розмовному мовленні «guу» вживається у значенні «штучка» [12]. В перекладі О. Логвиненка зберігається розмовне значення слова, але перекладач підбирає найбільш доцільне до української картини світу висловлювання, вживаючи вислів, загальноприйнятий в українській мові.

Суто авторським $є$ також переклад «That stuff gives me a bang sometimes» [10, c. 9] «Іноді це мене тішить» [9, с. 13]. В загальноприйнятому значенні «bang» означає «сильний удар», «стукіт», «чубчик», «звук вибуху», «м'яч», «хлопок» [12]. Переклад 
«bang» як «тішить» не $\epsilon$ варіантом розмовного мовлення, а такоє не $\epsilon$ сленгом. Це - суто авторське сприймання О.Логвиненком наведеної в тексті оригіналу діалогічної ситуації.

Висновки та перспективи подальшого дослідження. Ми пропонуємо додаткову стратегію у перекладі художніх творів, яку визначаємо як стратегію ампліфікації. Дана стратегія має місце у випадках, коли розмовна лексика в тексті оригіналу $є$, а слова, які стоять у сполученні з цією розмовною лексикою, навпаки відсутні, їх пропонує перекладач, додумуючи те, що не довисловлював автор у художньому творі. В даному разі перекладачем використовується механізм антиципації, тобто прогнозування контексту з опорою на попередній текст, i, врешті-решт, відбувається ампліфікація висловлювання. Подібними до описаних $є$ випадки, коли розмовна лексика зберігається лише в тексті перекладу, а в оригіналі вона взагалі відсутня. До ампліфікованих висловлювань ми відносимо також й ті, що в тексті Дж.Д.Селінджера мають в своїй структурі графон (graphon) - стилістичний засіб, який в даному тексті підсилює та підкреслює розмовний стиль та особливості вживання автором побутової лексики, наголошує на розмовному стилі мовлення учасників діалогічної ситуації. Перекладач, відповідно, вдало використовує розмовну лексику української мови для відтворення змісту тексту. Приклади ампліфікації висловлювань в перекладі та їхній психологічний аналіз будуть наведені в наступних наших публікацій. Також в наступних наших статтях окреслимо наступну стратегію, яку використовує О. Логвиненко для перекладу роману Дж. Д. Селінджера «Над прірвою у житі», а саме стратегію «включення в текст додаткових елементів або авторські вкраплення у перекладі», яка за своїм змістом також є суто психологічною.

\section{Перелік використаних джерел:}

1. Долга Т. О. Переклад як вид мовленнєвої діяльності / T.О. Долга // Матеріали III Міжнародної науковопрактичній конференції [“Міжкультурна комунікація: мова - культура - особистість"], (Остріг, 2-3 квітня 2009 р.). - Остріг, 2009. - Вип. 11. - С. 13-17.

2. Зимняя И. А. Психологические аспекты обучения говорению на иностранном языке / Ирина Алексеевна Зимняя. - М. : Просвещение, 1978. - С. 19-23.

3. Кетфорд Дж. К. Лингвистическая теория перевода / Дж.К. Кетфорд // Вопросы теории перевода в зарубежной лингвистике. - М. : Международные отношения, 1978. - C. 91-114.

4. Коломієць Л. В. Перекладознавчі семінари : Актуальні теоретичні концепції та моделі аналізу поетичного перекладу : навчальний посібник / Лада Володимирівна Коломієць. - К. : Видавничо-поліграфічний центр «Київський університет», 2011. - 527 с.

5. Комиссаров В. Н. Лингвистика перевода / Вилен Наумович Комиссаров. - М. : Международные отношения, $1980 .-160 \mathrm{c}$.

6. Кочубей О. С. Структура та зміст підготовки викладачів перекладу в мовному вищому навчальному закладі [Текст] / Ольга Святославівна Кочубей // Зб. наук. пр. Наукові записки Рівненського державного гуманітарного університету [«Актуальні проблеми філології та методики викладання гуманітарних дисциплін»]. - Рівне : РДГУ, 2013. - С. 41-45. 
7. Крилова-Грек Ю. М. Психолінгвістичні особливості перекладу семантичних одиниць іншомовних текстів : дис. ... кандидата психол. наук : 19.00.01 / Юлія Михайлівна Крилова-Грек. - К., 2007. - 196 с.

8. Михальчук Н. О. Методологічні засади підготовки перекладачів у світлі Болонського процесу / Наталія Олександрівна Михальчук // Переклад у 21 столітті : Тези наукової конференції 11 березня 2005 року, м. Харків. - Харків, 2005. - С. 51-52.

9. Селінджер Дж. Д. Над прірвою у житі : [повісті, оповідання] / Джером Девід Селінджер // [в укр. перекладі Олекси Логвиненка]. - К. : Молодь, 1984. - 272 с.

10. Salinger J. D. The Catcher in the Rye / Jerom David Salinger. - OCR \& Spellcheck : Aerius, 2003. - 91 p.

11. Seleskovitch D. Interpretation, a Psychological Approach to Translating / D. Seleskovitch // [in : Ed. Richard W Brislig. Translation Applications and Research]. - New York Gardner Press, 1976. - P. 92-115.

\section{References (Transliteration):}

1. Dolha T. O. Pereklad jak vyd movlennievoji dijaĺnosti / T.O. Dolha // Materialy III Mižnarodnoji naukovopraktyčnij konferenciji ["Mijkuĺturna komunikacija: mova - kuĺtura - osobystist"'], (Ostrih, 2-3 kvitnia 2009 r.). Ostrih, 2009. - Vyp. 11. - S. 13-17.

2. Zimnyaya I. A. Psixologicheskie aspekty obucheniya govoreniyu na inostrannom yazyke / Irina Alekseevna Zimnyaya. - M. : Prosveshhenie, 1978. - S. 19-23.

3. Ketford Dzh. K. Lingvisticheskaya teoriya perevoda / Dzh.K. Ketford // Voprosy teorii perevoda v zarubezhnoj lingvistike. - M. : Mezhdunarodnye otnosheniya, 1978. - S. 91-114.

4. Kolomijeć L.V. Perekladoznavči seminary : Aktuaĺni teoretyčni koncepciji ta modeli analizu poetyčnoho perekladu : navčaĺný posibnyk / Lada Volodymyrivna Kolomijeć. - K. : Vydavnyčo-polihrafičný centr «Kýivśký universytet», 2011. $-527 \mathrm{~s}$.

5. Komissarov $V . \quad$. Lingvistika perevoda / Vilen
Naumovich Komissarov. - M. : Mezhdunarodnye otnosheniya, 1980. - $160 \mathrm{~s}$.

6. Kočubej $O$. S. Struktura ta zmist pidhotovky vykladačiv perekladu v movnomu vyščomu navčaĺnomu zakladi [Tekst] / Oĺha Sviatoslavivna Kočubej // Zb. nauk. pr. Naukovi zapysky Rivnenśkoho deržavnoho humanitarnoho universytetu [«Aktuaĺni problemy filolohiji ta metodyky vykladannia humanitarnych dyscyplin»). - Rivne : RDHU, 2013. - S. 41-45.

7. Krylova-Hrek Ju. M. Psycholinhvistyčni osoblyvosti perekladu semantyčnych odynyć inšomovnych tekstiv : dys. ... kandydata psychol. nauk : 19.00.01 / Julija Mychajlivna Krylova-Hrek. - K., 2007. - 196 s.

8. Mychaĺčuk N. O. Metodolohični zasady pidhotovky perekladačiv u svitli Bolonśkoho procesu / Natalija Oleksandrivna Mychaĺčuk // Pereklad u 21 stolitti : Tezy naukovoji konferenciji 11 bereznia 2005 roku, m. Charkiv. - Charkiv, 2005. - S. 51-52.

9. Selindžer Dž. D. Nad prirvoju u žyti : [povisti, opovidannia] / Džerom Devid Selindžer // [v ukr. perekladi Oleksy Lohvynenka]. - K. : Molod', 1984. - 272 s.

10. Salinger J. D. The Catcher in the Rye / Jerom David Salinger. - OCR \& Spellcheck : Aerius, 2003. - 91 p.

11. Seleskovitch D. Interpretation, a Psychological Approach to Translating / D. Seleskovitch // [in : Ed. Richard W Brislig. Translation Applications and Research]. - New York Gardner Press, 1976. - P. 92-115.

\section{Ivashkevych Ernest}

PhD student at the Department of Age and Pedagogical Psychology of Rivne State University of the Humanities, Rivne (Ukraine)

\section{PSYCHOLOGICAL ASPECTS OF THE AUTHOR'S STRATEGY OF TRANSLATION}

\section{ABSTRACT}

This paper describes the psychological aspects of translation. It was noted that the trans- 
lator had done speech mediation, with the help of which and because of a great role of the target language it was created a text which by its communicative characteristics could be perceived as the equivalent of the original. With the help of this communicative equivalence it was manifested the identification of the translation and the original in the functional, semantic and structural plans.

In the paper the problem of translation activity was outlined. It was emphasized that the most important task of translation was to show linguistic and extra-linguistic factors that were enable the identification of the content of messages transmitted in different languages.

The translation strategies were described. These strategies are taking place regarding the translation of literature, namely the inclusion of additional elements (author's inclusions into translation); the omission of elements of excess in terms of foreign readers; converting the semantic structure of words and phrases; translation by finding out compromise solutions; usage of adequate replacements (interpretation, antonymous translation, compensation, etc.); translation by finding out functional analog; the author's translation.

The peculiarities of the author's translation were characterized. It was noted that the author's translation had been achieved by a sufficiently important goal of a professional activity, such as displaying explicit and implicit meanings of the original in order to preserve maximum freedom of the interpretation. The author of the article showed the examples of the translation of the novel "The Catcher in the Rye" (the author of it J. D. Salinger is) by O. Lohvynenko using the strategy "the author's translation". There were outlined the cases of indirect translation which had the meaning of the introduction of the author's meaning, offered by the translator's interpretation. A strategy of amplification according to the translation of novels was proposed.

Key words: translation activity, linguistic factors, extra-linguistic factors, translation strategies, the author's translation, strategy of amplification.

\section{Ивашкевич Эрнест Эдуардович}

Переводчик, соискатель кафедры возрастной и педагогической психологии Ровенского государственного гуманитарного университета, Ровно (Украина)

\section{ПСИХОЛОГИЧЕСКИЕ АСПЕКТЫ АВТОРСКОЙ СТРАТЕГИИ ПЕРЕВОДА}

Аннотация. В статье описаны психологические аспекты переводческой деятельности. Отмечено, что переводчик осуществляет речевое посредничество, в условиях которого на языке перевода создаётся определённый текст, коммуникативно равноценный оригиналу, причём его коммуникативная равноценность проявляется в отождествлении переводчиком данного текста с оригиналом в функциональном, содержательном и структурном планах. 
Определены задачи переводческой деятельности. Отмечено, что важнейшей задачей переводческой деятельности является выявление языковых и экстралингвистических факторов, которые способствуют отождествлению содержания сообщения, передаваемого на разных языках.

Описаны переводческие стратегии, которые имеют место в плане перевода художественной литературы, а именно: включение в текст дополнительных элементов (авторские вкрапления в переводе); опущение элементов, избыточных с точки зрения иноязычного читателя; преобразование смысловой структуры слов и выражений; компромиссные переводческие решения; использование адекватных замен (интерпретация, антонимический перевод, компенсация и т.д.); нахождения функционального аналога; чисто авторский перевод.

Дана характеристика особенностям авторской стратегии перевода, направленной на достижение достаточно важной цели профессиональной деятельности переводчика, a именно - отражение эксплицитных и имплицитных значений оригинала с целью сохранения наибольшей свободы интерпретации. В статье в качестве примеров предложен перевод А. Логвиненком произведения Дж. Д. Селинджера «Над пропастью во ржи» с использованием стратегии «чисто авторский перевод». Определены и обоснованы случаи косвенного перевода текста с привнесением авторского смысла. Сформулирована дополни- тельная стратегия в переводе художественных произведений, которая определена как стратегия амплификации, обосновано содержание этой стратегии.

Ключевые слова: переводческая деятельность, языковые факторы, экстралингвистические факторы, переводческие стратегии, авторская стратегия перевода, стратегия амплификации. 